\title{
The NMDA receptor functions independently and as an LRP1 co-receptor to promote Schwann cell survival and migration
}

\author{
Elisabetta Mantuano ${ }^{1,2}$, Michael S. Lam ${ }^{1}$, Masataka Shibayama ${ }^{3}$, W. Marie Campana ${ }^{3,4}$ and Steven L. Gonias ${ }^{1, *}$
}

\begin{abstract}
NMDA receptors (NMDA-Rs) are ionotropic glutamate receptors, which associate with LDL-receptor-related protein-1 (LRP1) to trigger cell signaling in response to protein ligands in neurons. Here, we demonstrate for the first time that the NMDA-R is expressed by rat Schwann cells and functions independently and with LRP1 to regulate Schwann cell physiology. The NR1 (encoded by GRIN1) and NR2b (encoded by GRIN2B) NMDA-R subunits were expressed by cultured Schwann cells and upregulated in sciatic nerves following crush injury. The ability of LRP1 ligands to activate ERK1/2 (also known as MAPK3 and MAPK1, respectively) and promote Schwann cell migration required the NMDA-R. NR1 gene silencing compromised Schwann cell survival. Injection of the LRP1 ligands tissue-type plasminogen activator (tPA, also known as PLAT) or MMP9-PEX into crush-injured sciatic nerves activated ERK1/2 in Schwann cells in vivo, and the response was blocked by systemic treatment with the NMDA-R inhibitor MK801. tPA was unique among the LRP1 ligands examined because tPA activated cell signaling and promoted Schwann cell migration by interacting with the NMDA-R independently of LRP1, albeit with delayed kinetics. These results define the NMDA-R as a Schwann cell signaling receptor for protein ligands and a major regulator of Schwann cell physiology, which may be particularly important in peripheral nervous system (PNS) injury.
\end{abstract}

KEY WORDS: Schwann cell, Peripheral nerve, NMDA receptor, LRP1, Tissue-type plasminogen activator, MMP9, $\alpha_{2}$-macroglobulin

\section{INTRODUCTION}

The N-methyl-D-aspartate receptor (NMDA-R) is an extensively studied neuronal ionotropic glutamate receptor, composed of GluN1 (NR1, encoded by GRIN1) and GluN2 (NR2, encoded by GRIN2A-GRIN2D) subunits (Furukawa et al., 2005). Numerous activities have been described for the NMDA-R in neuronal development, including effects on cell migration, differentiation of progenitors and dendrite development (Nacher and McEwen, 2006; Rajan and Cline, 1998). In mature neurons, the NMDA-R localizes to post-synaptic densities, where it plays an important role in longterm potentiation based on its mechanism of channel activation that requires both glutamate and membrane depolarization (Bliss and Collingridge, 1993; Lynch, 2004). $\mathrm{Ca}^{2+}$ flux through the NMDA-R regulates cell signaling and, in turn, activated signaling factors regulate the function of the NMDA-R (Wang and Salter, 1994).

\footnotetext{
Department of Pathology, University of California San Diego, La Jolla, CA 92093 USA. ${ }^{2}$ Department of Experimental Medicine, Sapienza University of Rome, Rome 00161, Italy. ${ }^{3}$ Department of Anesthesiology, University of California San Diego, La Jolla, CA 92093, USA. 'The Program in Neuroscience, University of California San Diego, La Jolla, CA 92093, USA.

*Author for correspondence (sgonias@ucsd.edu)
}

Received 29 April 2015; Accepted 6 August 2015
Abnormal expression and mutations in the NMDA-R have been implicated in neurological and psychiatric disorders (Kemp and McKernan, 2002; Jansen and Dannhardt, 2003; Missale et al., 2006; Brown and Krupp, 2006). Drugs targeting the NMDA-R are used in anesthesia and pain management (Ji et al., 2003).

In post-synaptic densities in neurons, the NMDA-R is physically and functionally associated with receptors in the low-density lipoprotein (LDL) receptor family, including LDL-receptor-related protein-1 (LRP1) and ApoER2 (also known as LRP8) (Strickland et al., 2002; May et al., 2004; Hoe et al., 2006; Martin et al., 2008). Based on its interaction with LRP1, the NMDA-R functions as an essential signaling co-receptor for LRP1 ligands, including $\alpha_{2^{-}}$ macroglobulin $\left(\alpha_{2} \mathrm{M}\right)$, tissue-type plasminogen activator (tPA) and apolipoprotein E (Bacskai et al., 2000; Qiu et al., 2002; Samson et al., 2008; Martin et al., 2008; Sheng et al., 2008; Mantuano et al., 2013). LRP1 ligands have been implicated in neuronal survival (Hayashi et al., 2007; Fuentealba et al., 2009) and in neurite outgrowth (Mantuano et al., 2008a,b; Shi et al., 2009; Yoon et al., 2013). Unlike other LRP1 ligands, tPA interacts directly with the NMDA-R, independently of LRP1, triggering cell signaling, albeit with delayed kinetics (Nicole et al., 2001; Macrez et al., 2010; $\mathrm{Ng}$ et al., 2009; Mantuano et al., 2013). NR1 subunit cleavage is reported to be involved in the mechanism by which tPA activates the NMDA-R; however, NR1 cleavage might not be necessary (Nicole et al., 2001; Mantuano et al., 2008a,b).

Less is known about NMDA-Rs in cells other than neurons. The NMDA-R has been identified in oligodendrocyte processes and central nervous system (CNS) myelin (Salter and Fern, 2005; Micu et al., 2006). Cortical astrocytes and satellite cells express NMDARs, which might be involved in crosstalk with neurons (Lalo et al., 2006; Castillo et al., 2013). NMDA-Rs also have been identified in Schwann cells in guinea pig and squid (Evans et al., 1991; Fink et al., 1999); however, the function of Schwann cell NMDA-R remains undefined.

Schwann cells provide myelination and trophic support for axons (Jessen and Mirsky, 2005; Campana, 2007). In response to PNS injury, Schwann cells de-differentiate and acquire the ability to migrate and proliferate in a process termed 'Schwann cell activation' (Meier et al., 1999; Jopling et al., 2011; Arthur-Farraj et al., 2012). Activated Schwann cells carry out functions that are essential for nerve repair, including phagocytosis of debris, secretion of trophic factors and deposition of provisional extracellular matrix proteins. LRP1 is expressed by Schwann cells mainly after peripheral nervous system (PNS) injury (Campana et al., 2006) and functions as a robust cell signaling receptor (Mantuano et al., 2008a,b, 2010, 2011). LRP1initiated cell signaling supports Schwann cell survival and migration. When LRP1 is deleted conditionally in Schwann cells in mice, abnormalities in the response to PNS injury are observed, including accelerated demyelination, abnormal regeneration and neuropathic pain (Orita et al., 2013). The molecular nature of the LRP1 signaling system in Schwann cells remains uncharacterized. 
In this study, we show for the first time that the NMDA-R is expressed by rat Schwann cells and that expression is increased after PNS injury. The NMDA-R functions as an essential LRP1 coreceptor in Schwann cells and thus, is required for cell signaling in response to diverse LRP1 ligands, including $\alpha_{2} \mathrm{M}$, tPA and matrix metalloproteinase 9 (MMP9). Through its effects on cell signaling, the NMDA-R supports Schwann cell migration and survival. The NMDA-R also functions as an independent Schwann cell receptor for tPA, activating ERK1/2 (also known as MAPK3 and MAPK1, respectively) and promoting cell migration in response to tPA even when LRP1 is unavailable. These studies identify important activities for the NMDA-R in a non-neuronal cell type, the Schwann cell, as an independent receptor for the protein ligand tPA and as a co-receptor for LRP1.

\section{RESULTS}

\section{NMDA-R subunits are expressed by cultured Schwann cells}

To begin, we subjected extracts of primary cultures of rat Schwann cells to immunoblot analysis using an NR1-subunit-specific antibody. As a positive control, we examined extracts from rat dorsal root ganglia (DRGs). We also examined PC12 cells. Although some variants of PC12 cells are reported to express low levels of NMDA-R (Edwards et al., 2007), in our PC12 cell line, the NMDA-R is expressed and functional (Mantuano et al., 2013). As shown in Fig. 1A, NR1-specific antibody detected a protein in Schwann cell extracts with an apparent mass of 110-120 kDa. The mass of this species corresponds to the known mass of the NR1 subunit. The abundance of NMDA-R NR1 subunit in Schwann cell extracts was somewhat lower than in extracts of DRGs and PC12 cells. The mobility of the NR1 subunit band in Schwann cell extracts was slightly increased compared with the controls, probably reflecting differential glycosylation of this highly glycosylated gene product (Everts et al., 1997; Lichnerova et al., 2015).

To confirm that the detected band was the NR1 subunit, we transfected Schwann cells with NR1-specific small interfering RNA (siRNA, denoted siNR1). Fig. 1B shows that the level of NR1 mRNA in Schwann cells was decreased by $\sim 85 \%$ by gene silencing. NR1 gene silencing also substantially decreased the intensity of the $110-120-\mathrm{kDa}$ band in NR1 subunit immunoblots, confirming that the detected band was the NR1 subunit (Fig. 1C). As a control, we showed that NR1-specific siRNA had no effect on the cellular level of $\beta$-actin. Fig. $1 \mathrm{C}$ also shows that the NR2B NMDA-R subunit was detected in Schwann cell extracts by immunoblot analysis and unchanged by NR1 siRNA.

Schwann cells that were transfected with NR1-specific siRNA or with NTC siRNA were studied by immunofluorescence microscopy using primary antibody that detects NR1 subunit. Nuclei were labeled with DAPI. Fig. 1D shows that cultured Schwann cells, transfected with NTC siRNA, were uniformly immunopositive for NR1. NR1 gene silencing eliminated the NR1 immunofluorescence microscopy signal in essentially all of the cells.

\section{NMDA-R is necessary for LRP1 signaling in Schwann cells}

Binding of ligands to LRP1 regulates diverse cell signaling pathways in Schwann cells (Mantuano et al., 2008a,b, 2010). In this study, we examined ERK1/2 phosphorylation as an indicator of the multifaceted LRP1 signaling response. Fig. 2A shows that the LRP1 ligand activated $\alpha_{2} \mathrm{M}\left(\alpha_{2} \mathrm{M}^{*}\right)(10 \mathrm{nM})$ and the enzymatically inactive tPA (EI-tPA) $(12 \mathrm{nM})$, activated ERK1/2 in cultured Schwann cells. To confirm that this signaling response requires LRP1, we pre-treated Schwann cells with receptor-associated protein (RAP, also known as LRPAP1), which was expressed as a
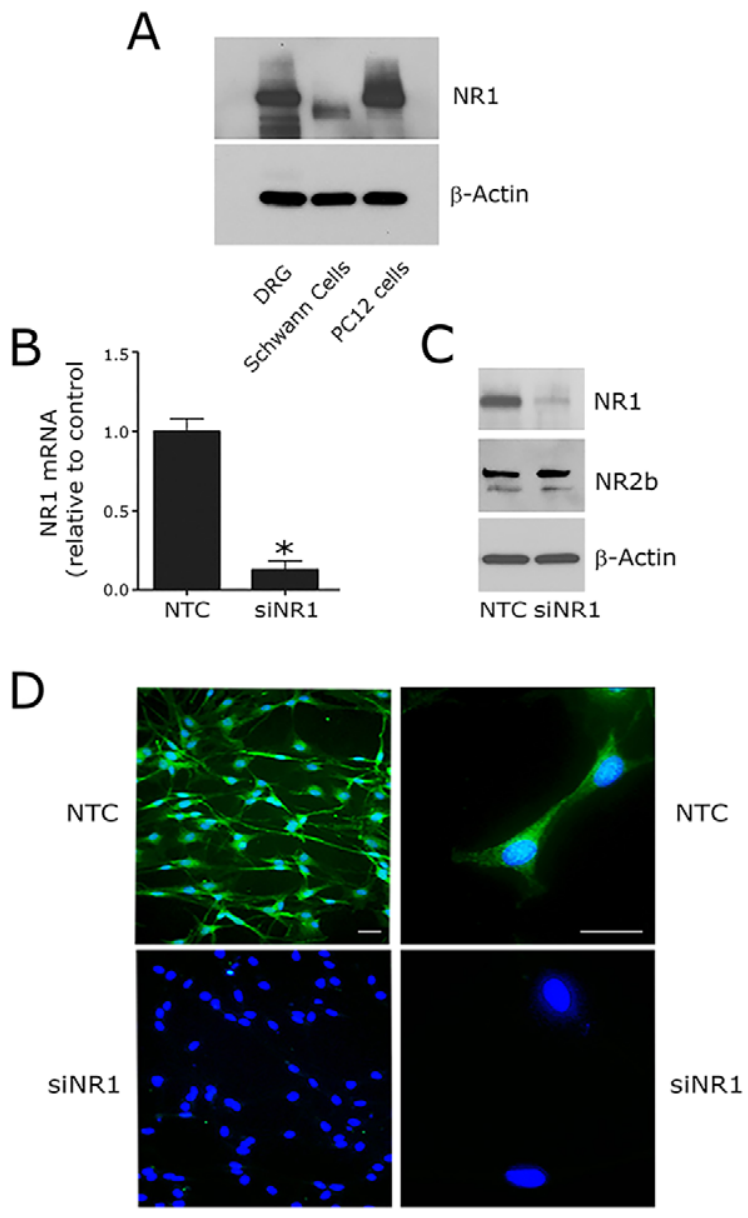

Fig. 1. NMDA-R is expressed by cultured Schwann cells. (A) NR1 protein was determined by immunoblot analysis in extracts of rat DRGs, Schwann cells and PC12 cells. Equal amounts of cellular protein $(60 \mu \mathrm{g})$ were loaded into each lane. Blots were re-probed for $\beta$-actin as a loading control. (B) NR1 mRNA was determined by qRT-PCR in Schwann cells transfected with NTC or NR1-specific siRNA (siNR1). (C) Primary cultures of Schwann cells were transfected with NTC siRNA or siNR1. The levels of NR1 and NR2b were determined by immunoblot analysis $48 \mathrm{~h}$ after transfection. Blots were reprobed for $\beta$-actin as a loading control. (D) Immunofluorescence microscopy was performed to detect NR1 immunoreactivity in Schwann cells transfected with NTC or NR1-specific siRNA. Nuclei were stained with DAPI (blue). Scale bars: $20 \mu \mathrm{m}$.

GST-fusion protein (GST-RAP) $(150 \mathrm{nM})$. RAP is a wellestablished LRP1 cell signaling antagonist (Strickland et al., 2002). We also pre-treated cells with lactoferrin (150 nM), which in neurons and neuron-like cells, functions similarly to RAP, binding to LRP1 and preventing activation of cell signaling by other ligands (Mantuano et al., 2013). RAP and lactoferrin both blocked ERK1/2 activation in Schwann cells in response to $\alpha_{2} \mathrm{M}^{*}$ and EI-tPA.

In neurons, LRP1 signaling requires the NMDA-R as an essential co-receptor (Bacskai et al., 2000; Qiu et al., 2002; Samson et al., 2008; Martin et al., 2008; Sheng et al., 2008; Mantuano et al., 2013). Other LRP1 co-receptors in neurons include Trk receptors and p75 ${ }^{\text {NTR }}$ (Shi et al., 2009; Yoon et al., 2013; Stiles et al., 2013). Very little is known about the molecular nature of the LRP1 signaling system in other cell types. To test whether the NMDA-R is required for LRP1 signaling in Schwann cells, first we pre-treated Schwann cells with MK801 $(1 \mu \mathrm{M})$, an uncompetitive antagonist of the NMDA-R. Fig. 2B shows that MK801 blocked ERK1/2 phosphorylation in response to $\alpha_{2} \mathrm{M}^{*}$ and EI-tPA. In control 
A

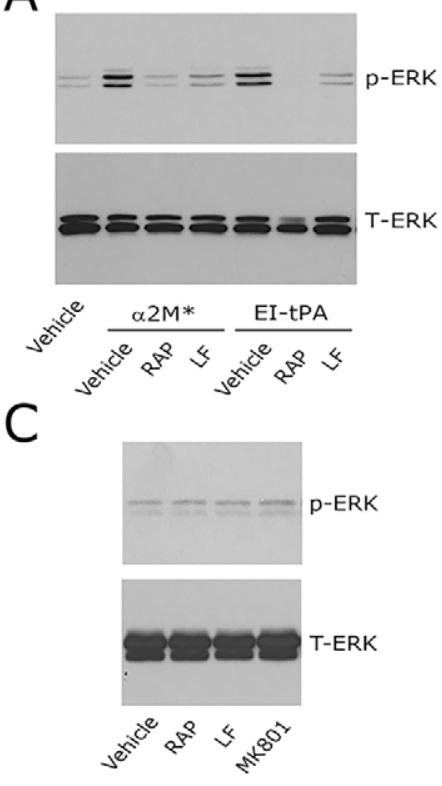

B

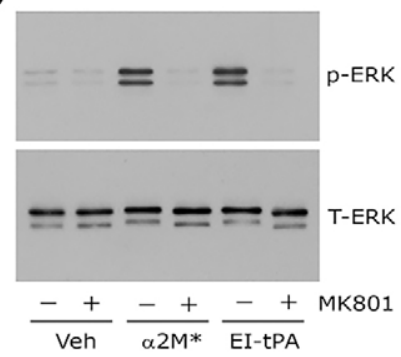

$\mathrm{D}$

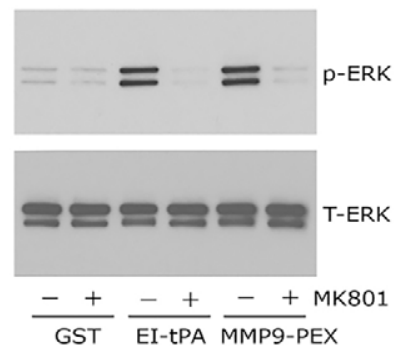

$\mathrm{E}$

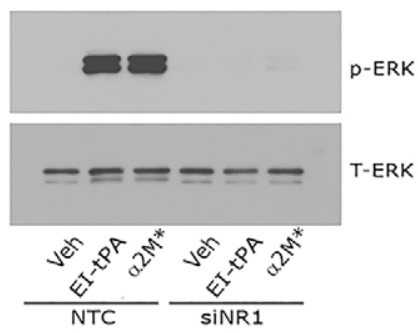

$\mathrm{F}$

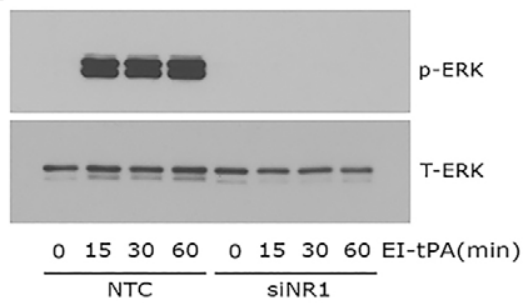

Fig. 2. Neutralizing the NMDA-R blocks ERK1/2 activation in response to LRP1 ligands in Schwann cells. (A) Primary

cultures of Schwann cells were pre-treated with 150 nM GST-RAP (RAP), $150 \mathrm{nM}$ lactoferrin (LF) or with vehicle (PBS) for $30 \mathrm{~min}$ and then with $\alpha_{2} \mathrm{M}^{*}(10 \mathrm{nM})$ or El-tPA $(12 \mathrm{nM})$ for $10 \mathrm{~min}$. (B) Schwann cells were pre-treated with $1 \mu \mathrm{M}$ MK801 (+) or with vehicle (-) for $30 \mathrm{~min}$ and then with $\alpha_{2} \mathrm{M}^{*}(10 \mathrm{nM})$, El-tPA $(12 \mathrm{nM})$ or vehicle (PBS) for 10 min. (C) Schwann cells were treated with GST-RAP (150 nM), lactoferrin (150 nM) or MK801 (1 $\mu \mathrm{M})$ for $30 \mathrm{~min}$. (D) Schwann cells were pre-treated with $1 \mu \mathrm{M}$ MK801 (+) or with vehicle (-) for $30 \mathrm{~min}$ and then with GST (20 nM), EI-tPA (12 nM), or GST-PEX (20 nM) for $10 \mathrm{~min}$. (E) Schwann cells in which NR1 was silenced and control cells transfected with NTC siRNA were treated with El-tPA (12 nm) or $\alpha 2 \mathrm{M}^{*}(10 \mathrm{nM})$ for $10 \mathrm{~min}$. (F) Primary cultures of Schwann cells in which NR1 was silenced and control cells transfected with NTC siRNA were treated with El-tPA $(12 \mathrm{~nm})$ for various times up to $1 \mathrm{~h}$. Equal amounts of cellular protein $(40 \mu \mathrm{g})$ were loaded into each lane and subjected to SDS-PAGE. Immunoblot analysis was performed to detect phosphorylated ERK1/2 ( $p-E R K)$ and total ERK1/2 (T-ERK). Each blot represents $3-5$ independent studies. experiments, we demonstrated that MK801 and the LRP1 antagonists, RAP and lactoferrin, do not independently regulate phosphorylated (p-)ERK1/2 in Schwann cells (Fig. 2C). MK801 also inhibited the ERK1/2 activation in response to a GST fusion protein that contains the hemopexin domain of MMP9 (GST-PEX, $20 \mathrm{nM}$ ), known to bind to LRP1 (Mantuano et al., 2008a,b) (Fig. 2D).

Next, we examined the effects of NR1 gene silencing on LRP1initiated cell signaling. In Schwann cells, that were transfected with non-targeting control (NTC) siRNA and treated with $\alpha_{2} \mathrm{M}^{*}$ or EI-tPA for $10 \mathrm{~min}$, ERK1/2 was activated. In cells transfected with NR1specific siRNA, the response to $\alpha_{2} \mathrm{M}^{*}$ and EI-tPA was completely blocked (Fig. 2E). Fig. 2F shows that, in Schwann cells transfected with NTC siRNA, the response to EI-tPA $(12 \mathrm{nM})$ was sustained through $60 \mathrm{~min}$. In cells transfected with NR1-specific siRNA, ERK1/2 activation was blocked throughout the entire incubation period. These NR1 gene silencing experiments support the results of our MK801 studies and suggest that NMDA-R is essential for activation of cell signaling by $\alpha_{2} \mathrm{M}^{*}$ and tPA in Schwann cells.

\section{The NMDA-R in Schwann cell migration and survival}

Ligand binding to LRP1 in Schwann cells promotes cell migration (Mantuano et al., 2008a,b). Although LRP1 controls multiple signaling pathways that regulate cell migration, in response to LRP1 ligands, migration is stimulated mainly due to activation of ERK1/2 (Mantuano et al., 2008a,b, 2010). We tested the ability of MK801 to block Schwann cell migration in response to EI-tPA and $\alpha_{2} \mathrm{M}^{*}$ using our previously described Transwell model system (Mantuano et al., 2008a,b). Fig. 3 shows that, in absence of MK801, EI-tPA and $\alpha_{2} \mathrm{M}^{*}$ increased Schwann cell migration more than fivefold
$(P<0.01)$. MK801 had no effect on Schwann cell migration in the absence of LRP1 ligands; however, MK801 completely blocked the response to EI-tPA and $\alpha_{2} \mathrm{M}^{*}$.

Next, we compared Schwann cells transfected with NR1-specific or NTC siRNA. As shown in Fig. 4A,B, in cells transfected with NTC siRNA, EI-tPA and $\alpha_{2} \mathrm{M}^{*}$ promoted cell migration. The response to EI-tPA and $\alpha_{2} \mathrm{M}^{*}$ was entirely blocked by NR1 gene silencing. These results and those of our MK801 studies demonstrate that NMDA-R is essential in the pathway by which tPA and $\alpha_{2} \mathrm{M}^{*}$ promote Schwann cell migration.

LRP1 also has been implicated in Schwann cell survival (Campana et al., 2006). We therefore tested the effects of NR1 gene silencing on Schwann cell survival. Cells were exposed to low-serum medium (LSM) or LSM supplemented with TNF $\alpha(50 \mathrm{ng} / \mathrm{ml})$ for $18 \mathrm{~h}$. Under both sets of conditions, Schwann cell viability was compromised. The extent of compromise was significantly increased in cells in which the NR1 gene was silenced $(P<0.05)$ (Fig. 4C). We therefore conclude that the effects of NMDA-R NR1 gene silencing are equivalent to those observed when LRP1 is silenced or when its activity is antagonized (Campana et al., 2006; Mantuano et al., 2008a,b).

\section{Schwann cell NMDA-R activates cell signaling in response to tPA independently of LRP1}

In neurons, tPA can trigger cell signaling through a direct interaction with the NMDA-R, independently of LRP1 (Nicole et al., 2001; Macrez et al., 2010; $\mathrm{Ng}$ et al., 2012; Mantuano et al., 2013). To determine whether the NMDA-R signals in response to tPA, independently of LRP1 in Schwann cells, we treated Schwann cells with $12 \mathrm{nM}$ EI-tPA in the presence or absence of RAP 
A
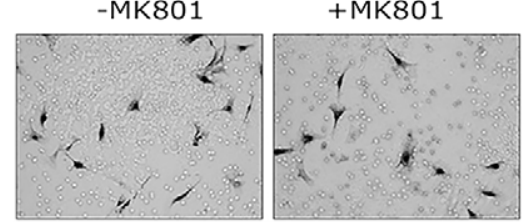

Vehicle
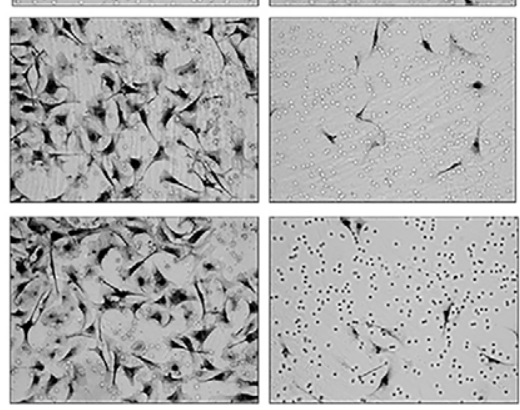

EI-tPA $\alpha 2 M^{*}$

B

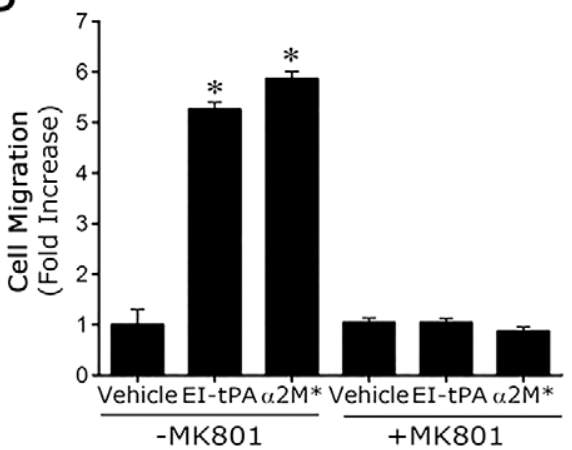

Fig. 3. NMDA-R antagonism inhibits the ability of LRP1 ligands to promote Schwann cell migration. (A) Images of Schwann cells that migrated across Transwell membranes to the lower surfaces. The cells were pre-treated with MK801 $(1 \mu \mathrm{M})$ for $15 \mathrm{~min}$ and then treated with El-tPA (12 nM), $\alpha_{2} \mathrm{M}^{*}$ $(10 \mathrm{nM})$ or vehicle (PBS). The LRP1 ligands were added to the Transwell chambers. Migration was allowed to proceed for $4 \mathrm{~h}$. (B) Quantification of cell migration results. Data are expressed as the mean \pm s.e.m. $\left(n=6-8,{ }^{*} P<0.01\right.$ compared with the vehicle control)

for up to $60 \mathrm{~min}$. At $15 \mathrm{~min}$, RAP blocked the response to EI-tPA, confirming the results of experiments reported in Fig. 1A. However, by $30 \mathrm{~min}$, ERK1/2 was activated even when binding of EI-tPA to LRP1 was prevented with RAP (Fig. 5A). The activity of RAP, blocking ERK1/2 phosphorylation in response to EI-tPA, was also overcome by increasing the EI-tPA concentration (Fig. 5B). These results suggest that in Schwann cells, as in PC12 and N2A cells (Mantuano et al., 2013), EI-tPA signals by binding to the NMDA-R, independently of LRP1; however, LRP1 facilitates a more rapid response or increases the sensitivity of the system.

As a control, we studied the Schwann cell response to $10 \mathrm{nM} \alpha_{2} \mathrm{M}^{*}$ as a function of time, up to $60 \mathrm{~min}$, in the presence or absence of RAP. We selected $\alpha_{2} \mathrm{M}^{*}$ for these control experiments because the binding affinity of $\alpha_{2} \mathrm{M}^{*}$ for LRP1 is much higher than the affinity of tPA for LRP1 (Ney et al., 1985; Hussaini et al., 1990; Bu et al., 1992). Although ERK $1 / 2$ was robustly activated by $\alpha_{2} M^{*}$ in the absence of RAP through the entire 60 min timecourse, when RAP was present, p-ERK1/2 was not observed (Fig. 5C). Increasing the concentration of $\alpha_{2} M^{*}$ to $60 \mathrm{nM}$ also failed to overcome the activity of RAP (Fig. 5D). Thus, for $\alpha_{2} \mathrm{M}^{*}$-initiated cell signaling in Schwann cells, unlike cell signaling stimulated by EI-tPA, the requirement for LRP1 appears absolute. For both EI-tPA and $\alpha_{2} \mathrm{M}^{*}$, the requirement for NMDA-R is absolute.
A
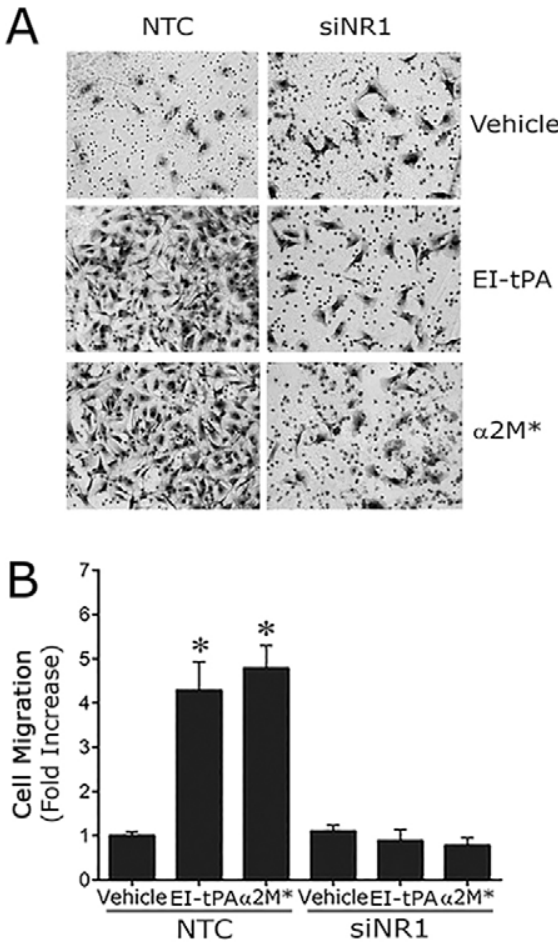

C

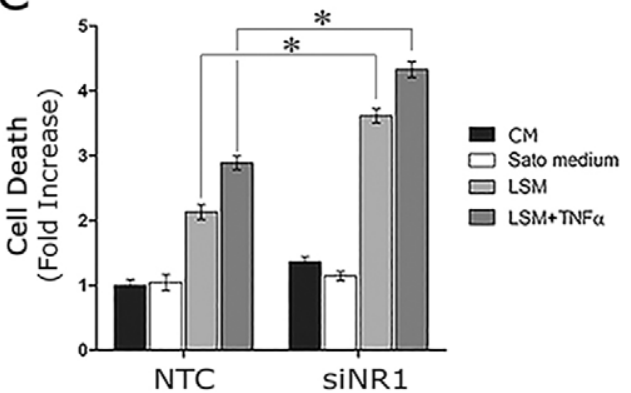

Fig. 4. NR1 gene silencing in Schwann cells blocks cell migration in response to LRP1 ligands. (A) Images of Schwann cells, transfected with NTC or NR1-specific siRNA, which migrated to the underside surface of Transwell membranes. The cells were treated with El-tPA $(12 \mathrm{~nm}), \alpha_{2} \mathrm{M}^{*}$ $(10 \mathrm{nM})$ or vehicle (PBS). Migration was allowed to proceed for $4 \mathrm{~h}$. (B) Quantification of cell migration results. Data are expressed as the mean \pm s.e.m. ( $n=6,{ }^{*} P<0.01$ compared with the vehicle control). (C) Schwann cell death was measured using the cell death ELISA in cells transfected with NTC siRNA or NR1-specific siRNA, after culturing for $4 \mathrm{~h}$ in complete medium (10\% FBS, CM), Sato medium, 0.5\% FBS-containing medium (LSM), or LSM plus TNF $\alpha(50 \mathrm{ng} / \mathrm{ml})$. The mean \pm s.e.m. is shown $\left(n=4,{ }^{*} P<0.05\right)$.

To further test whether EI-tPA interacts with the NMDA-R to regulate Schwann cell physiology in the absence of LRP1, we examined the ability of EI-tPA to stimulate Schwann cell migration in the presence of RAP. As shown in Fig. 6A, Schwann cell migration in response to $12 \mathrm{nM}$ EI-tPA was blocked by $150 \mathrm{nM}$ RAP. By contrast, $60 \mathrm{nM}$ EI-tPA overcame the inhibitory effects of RAP, stimulating cell migration by $5.4 \pm 0.3$ fold (mean \pm s.e.m.). As a control, we examined cell migration in response to different concentrations of $\alpha_{2} M^{*}$. As shown in Fig. $6 B, \alpha_{2} M^{*}$ failed to promote Schwann cell migration in the presence of $150 \mathrm{nM}$ RAP when added at a concentration of $10 \mathrm{nM}$ or $60 \mathrm{nM}$.

As a second approach to study the effects of EI-tPA on Schwann cell migration in the absence of LRP1, we silenced LRP1 expression in Schwann cells as previously described (Mantuano et al., 


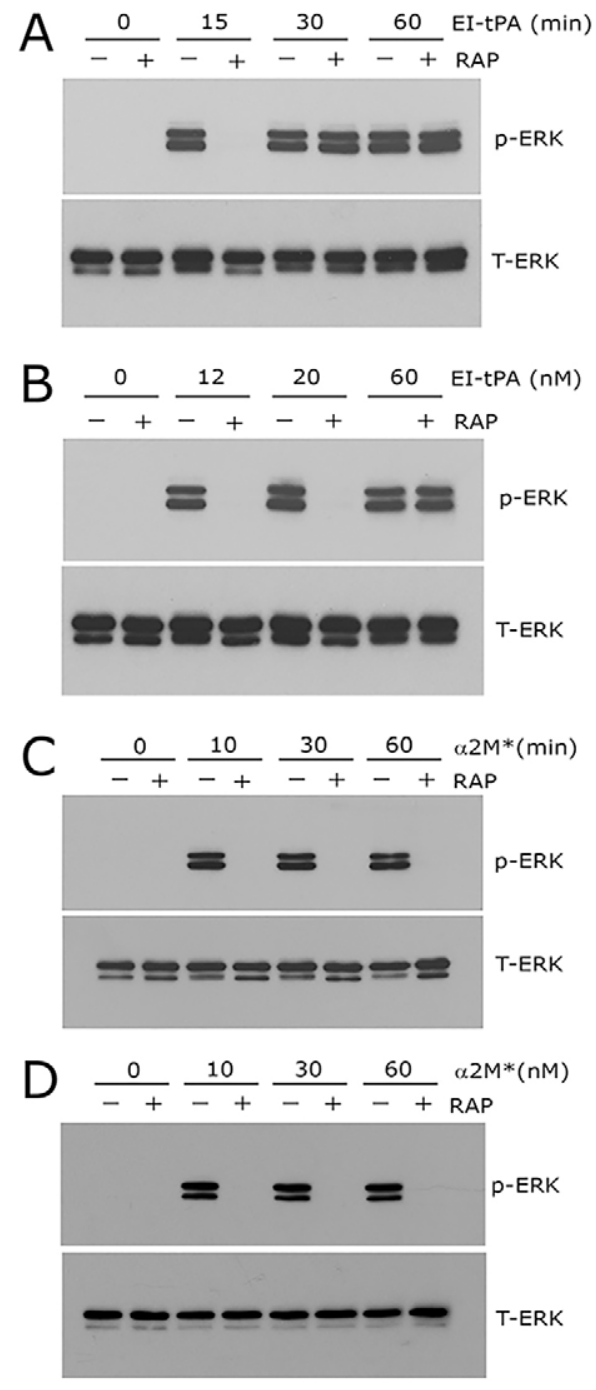

Fig. 5. tPA initiates NMDA-R-dependent cell signaling in the absence of LRP1 with delayed kinetics. (A) Primary cultures of Schwann cells were pretreated with $150 \mathrm{nM} \mathrm{GST-RAP} \mathrm{(+)} \mathrm{or} \mathrm{with} \mathrm{vehicle} \mathrm{(-)} \mathrm{for} 30 \mathrm{~min}$ and then El-tPA $(12 \mathrm{~nm})$ for the indicated times. (B) Schwann cells were pretreated with GST-RAP $(150 \mathrm{~nm})$ or with vehicle for $30 \mathrm{~min}$ and then with increasing concentrations of EI-tPA (12-60 nM) for $10 \mathrm{~min}$. (C) Schwann cells were pre-treated with $150 \mathrm{nM}$ GST-RAP (+) or with vehicle $(-)$ and then $\alpha_{2} \mathrm{M}^{*}$ $(10 \mathrm{nM})$ for up to $60 \mathrm{~min}$. (D) Schwann cells were treated with increasing concentrations of $\alpha_{2} \mathrm{M}^{*}$ for $10 \mathrm{~min}$. Equal amounts of cellular protein $(40 \mu \mathrm{g})$ were loaded into each lane and immunoblot analysis was performed to detect phosphorylated ERK1/2 ( $p$-ERK) and total ERK1/2 (T-ERK).

2008a,b). Compared with cells transfected with NTC siRNA, LRP1-silenced cells demonstrated $>95 \%$ reduction in LRP1 mRNA (results not shown). Fig. 6C shows that LRP1 gene silencing blocked Schwann cell migration in response to $12 \mathrm{nM}$ EI-tPA. In response to $60 \mathrm{nM}$ EI-tPA, a breakthrough response was observed; migration was stimulated $3.2 \pm 0.2$ fold $(P<0.01)$. Schwann cell migration in response to $12 \mathrm{nM}$ EI-tPA or $60 \mathrm{nM}$ EI-tPA was totally inhibited by MK801 (Fig. 6D).

\section{Enzymatically active and inactive tPA activate cell signaling in Schwann cells similarly}

When the enzymatic activity of tPA is not blocked, the NR1 subunit of the NMDA-R may be cleaved (Nicole et al., 2001). Active tPA also may release LRP1 from the surfaces of cells (Polavarapu et al.,
2007). We therefore conducted cell signaling experiments to determine whether enzymatically active tPA (EA-tPA) and inactive tPA yield equivalent results. Fig. 7A shows that EA-tPA activated ERK1/2 in cultured Schwann cells. The response was blocked by RAP when the concentration of EA-tPA was $12 \mathrm{nM}$; however, the inhibitory activity of RAP was overcome by higher concentrations of EA-tPA $(60 \mathrm{nM})$. Extending the incubation time also overcame the inhibitory activity of RAP (Fig. 7B). ERK1/2 activation in response to EA-tPA was blocked by MK801 (Fig. 7C). These results suggest that EA-tPA and EI-tPA activate cell signaling in Schwann cells equivalently.

\section{Sciatic nerve crush injury promotes expression of Schwann cell NMDA-R}

In rats, LRP1 expression is robustly increased in Schwann cells in response to PNS injury (Campana et al., 2006). Schwann cells account for $>90 \%$ of the mRNA present in the un-injured PNS and in the injured PNS for up to 2-3 days, before inflammatory cells infiltrate the injury site in significant numbers (Asbury and Johnson, 1978). We therefore performed quantitative real-time PCR (qRT-PCR) to test the effects of sciatic nerve crush injury on the NMDA-R subunit expression in vivo. Fig. 8A shows that LRP1 mRNA was significantly increased in the distal segment of the sciatic nerve, $24 \mathrm{~h}$ after crush injury. This result confirms our previous study, in which we proved that the increase in LRP1 mRNA was due to regulation of Schwann cell LRPl gene expression (Campana et al., 2006). Sciatic nerve crush injury also increased expression of NMDA-R subunits in distal segments, including NR1 $(P<0.05$, Fig. 8B) and NR2b $(P<0.05$, Fig. 8D). Although a trend towards increased NR2a mRNA expression was observed, the trend was not statistically significant (Fig. 8C).

\section{MK801 blocks Schwann cell LRP1 signaling in vivo}

Direct injection of the hemopexin domain of MMP-9 (MMP9-PEX) into crush-injured sciatic nerves activates ERK1/2 in Schwann cells in a response that is LRP1 dependent, as determined by co-injection of RAP (Mantuano et al., 2008a,b). ERK1/2 activation is not observed when MMP9-PEX is injected into uninjured nerves, probably because the level of Schwann cell LRP1 is extremely low in the uninjured PNS. In this study, for the first time, we injected EItPA into sciatic nerves, immediately distal to the injury site, $24 \mathrm{~h}$ after crush injury. We also injected MMP9-PEX, to collect results with a second LRP1 ligand. Fig. 8E shows that in control, uninjured nerves, p-ERK1/2 was minimally activated, as anticipated (Mantuano et al., 2008a,b). When rats were treated systemically with MK801 for $45 \mathrm{~min}$ prior to harvesting uninjured nerves, little or no effect on ERK1/2 activation was observed.

p-ERK1/2 remained only modestly activated in crush-injured sciatic nerves when the nerves were injected with vehicle, and once again, systemic pre-treatment with MK801 failed to significantly affect this result. By contrast, as shown in Fig. 8E, direct injection of EI-tPA into crush-injured sciatic nerves robustly activated ERK1/2. Systemic treatment of the rats with MK801 (intraperitoneal injection), for $30 \mathrm{~min}$ prior to injecting EI-tPA, blocked the response to EI-tPA. MMP9-PEX also activated ERK1/2 in crush-injured sciatic nerves, as anticipated (Mantuano et al., 2008a,b), and the response to MMP9PEX was blocked by systemic administration of MK801. Overall, MK801 inhibited cell signaling in vivo in response to one ligand (MMP9-PEX), which is known to bind only to LRP1, and to a second ligand (EI-tPA), which binds to LRP1 and/or the NMDA-R. These results suggest that the NMDA-R is essential for LRP1 signaling in Schwann cells in vivo in the injured PNS. 


\section{A}
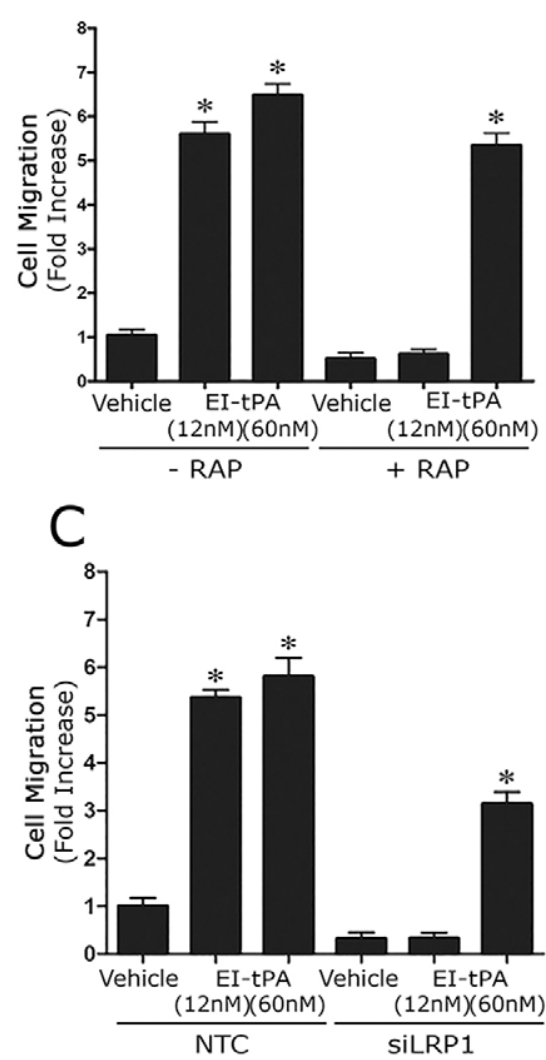

B

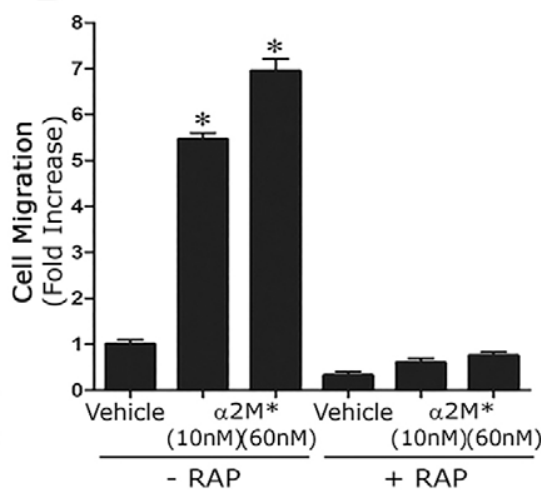

D

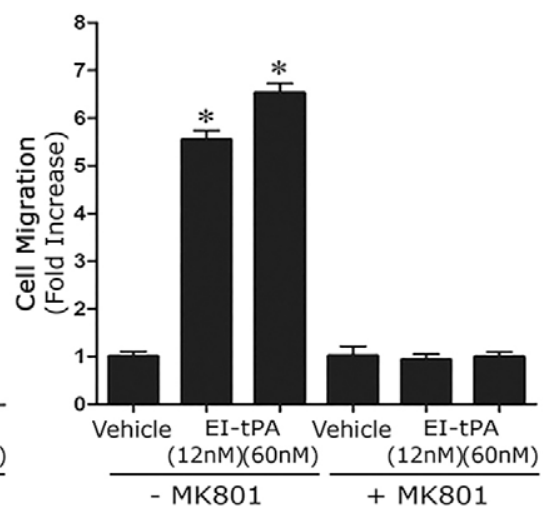

Fig. 6. tPA promotes Schwann cell migration by binding to the NMDA-R, independently of LRP1. (A) Primary cultures of Schwann cells were pre-treated with $150 \mathrm{nM}$ GST-RAP (+) or with vehicle $(-)$ for $15 \mathrm{~min}$ and then with the indicated concentration of El-tPA (12 or $60 \mathrm{nM}$ ). The EI-tPA and RAP were added to the Transwell chambers. Migration was allowed to proceed for $4 \mathrm{~h}$. (B) Schwann cells were pretreated with $150 \mathrm{nM}$ GST-RAP (+) or with vehicle $(-)$ and then with $\alpha_{2} \mathrm{M}^{*}$ at the indicated concentration (10 or $60 \mathrm{nM}$ ) before migration was allowed to proceed for $4 \mathrm{~h}$. (C) Schwann cells, transfected with NTC or NR1-specific siRNA, were treated with the indicated concentration of El-tPA (12 or $60 \mathrm{nM}$ ) or vehicle (PBS) and allowed to migrate for $4 \mathrm{~h}$. (D) Schwann cells were pre-treated with MK801 $(1 \mu \mathrm{M})$ for $15 \mathrm{~min}$ and then treated with El-tPA at the indicated concentration (12 or $60 \mathrm{nM}$ ). Data are expressed as the mean \pm s.e.m. $\left(n=6-8,{ }^{*} P<0.01\right.$ compared with the vehicle control).
To confirm that ERK1/2 activation occurred in Schwann cells when EI-tPA was injected into crush-injured sciatic nerves, we harvested tissue distal to the crush injury site and performed immunofluorescence microscopy microscopy to detect p-ERK1/2, as previously described (Mantuano et al., 2008a,b). Fig. 8F shows that p-ERK1/2 immunofluorescence microscopy was clearly present in nucleated crescent-shaped Schwann cells following EI-tPA injection. In animals that were pre-treated with MK801 systemically, Schwanncell-associated p-ERK1/2 immunofluorescence microscopy appeared decreased. Although immunofluorescence microscopy is not an appropriate technique to measure antigen levels quantitatively, the studies shown in Fig. 8F confirm that ERK1/2 is activated in Schwann cells in vivo when EI-tPA is injected into injured sciatic nerves and the NMDA-R is un-inhibited.

\section{DISCUSSION}

In this study, for the first time, we demonstrated that rat Schwann cells express NMDA-R. We also elucidated an essential role for Schwann cell NMDA-R as a signaling receptor in response to proteins known to be present in the injured PNS. Our results support a model in which the NMDA-R can be an important regulator of Schwann cell physiology. Schwann cells are known to release glutamate that interacts with neuronal NMDA-R (Wu et al., 2005); however, only a few previous reports have shown that NMDA-Rs are expressed by glia and might have significant functions in these cells. Satellite glial cells in DRGs apparently express the NMDA-R, which might contribute to interactions with neurons (Castillo et al., 2013). NMDA-R activation in satellite cells has been linked to sensitization of nociceptors and peripheral hyperalgesia (Ferrari et al., 2014). The NMDA-R also has been identified in oligodendrocyte precursor cells, where it might function in differentiation and myelination ( $\mathrm{Li}$ et al., 2013). In astrocytes, the NMDA-R regulates the production of the neuronal NMDA-R coagonist D-serine (Van Horn et al., 2013). Our new results suggest a highly expanded scope of activity for the NMDA-R as a receptor for protein ligands in Schwann cells in the injured PNS.

LRP1 has been identified as a regulator of inflammation and tissue remodeling in diverse cell types (Gonias and Campana, 2014). The increase in Schwann cell LRP1 expression that accompanies PNS injury is consistent with this model. When the LRPl gene is deleted in Schwann cells in mice, numerous abnormalities are observed following sciatic nerve injury, including accelerated demyelination, increased infiltration of the nerve by inflammatory cells, and abnormal regeneration (Orita et al., 2013). Because injecting RAP directly into injured sciatic nerves blocks LRP1 signaling and promotes Schwann cell death (Campana et al., 2006; Mantuano et al., 2008a,b), we hypothesize that in nerve injury, endogenously produced LRP1 ligands with agonistic signaling activity, such as MMP9 or tPA, activate the LRP1 signaling system, preventing the changes observed in conditional LRP1 gene knockout mice.

Results presented in this study demonstrated that the NMDA-R is required for activation of ERK1/2 in response to multiple LRP1 ligands $\left(\alpha_{2} \mathrm{M}^{*}\right.$, tPA and MMP9-PEX) in Schwann cells in vitro. The requisite role of the NMDA-R in Schwann cell LRP1 signaling suggested that previously demonstrated activities of Schwann cell LRP1 also might require the NMDA-R. We tested this hypothesis in a variety of experiments. The NMDA-R was required for LRP1ligand-stimulated cell migration. Furthermore, NMDA-R NR1 gene silencing compromised Schwann cell viability under stressful cell culture conditions. The effects of NRI gene silencing in cell death ELISA assays were similar to those observed when we silenced LRP1 gene expression in Schwann cells (Campana et al., 2006). 


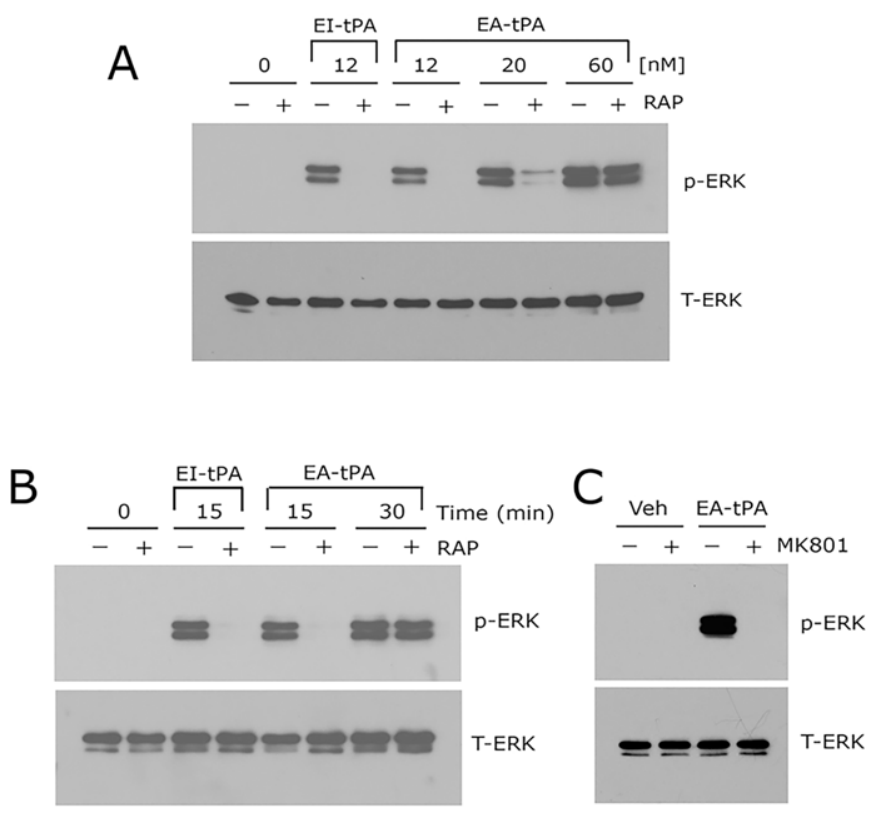

Fig. 7. Enzymatically active tPA activates ERK1/2 in Schwann cells in a similar manner to EI-tPA. (A) Primary cultures of Schwann cells were pretreated with $150 \mathrm{nM} \mathrm{GST-RAP} \mathrm{(+)} \mathrm{or} \mathrm{with} \mathrm{vehicle} \mathrm{(-)} \mathrm{for} 30 \mathrm{~min}$ and then with increasing concentrations of enzymatically active tPA (EA-tPA, 12-60 nM) or with $12 \mathrm{nM}$ El-tPA as a control. (B) Schwann cells were pretreated with GST-RAP (150 nM) or with vehicle for $30 \mathrm{~min}$ and then EA-tPA (12 nM) for 15 or $30 \mathrm{~min}$. Cells were treated with $12 \mathrm{nM}$ El-tPA for $15 \mathrm{~min}$ as a control. (C) Schwann cells were pre-treated with $1 \mu \mathrm{M} \mathrm{MK801} \mathrm{(+)} \mathrm{or} \mathrm{with} \mathrm{vehicle} \mathrm{(-)} \mathrm{for} 30 \mathrm{~min}$ and then with EA-tPA (12 nM) for $10 \mathrm{~min}$. Equal amounts of cellular protein $(40 \mu \mathrm{g})$ were loaded into each lane and immunoblot analysis was performed to detect phosphorylated ERK1/2 ( $p-E R K)$ and total ERK1/2 (T-ERK).

Finally, treating rats systemically with MK801 blocked the ability of MMP9-PEX and EI-tPA to activate ERK1/2 in Schwann cells when the protein ligands were injected directly into crush-injured sciatic nerves. These results suggest that NMDA-R functions in Schwann cell signaling and as an essential Schwann cell LRP1 cell signaling co-receptor in vivo. By analogy with the role of Schwann cell LRP1 in vivo (Orita et al., 2013), we hypothesize that Schwann cell NMDA-R might be important in determining the rate and extent of demyelination following PNS injury, in preventing excessive neuroinflammation, and in functional nerve regeneration. Further work using conditional gene deletion model systems will be necessary to further explore the activity of Schwann cell NMDA-R in vivo, independently of neuronal NMDA-R.

We applied two methods to show that Schwann cell signaling responses require the NMDA-R: pharmacological antagonism and gene silencing. To show that LRP1 is required, we blocked responses with two separate LRP1 antagonists, RAP and lactoferrin. In previous studies, we also applied LRP1 gene silencing with equivalent results (Mantuano et al., 2008a,b, 2010). To test the role of the NMDA-R in Schwann cell LRP1 signaling, we chose to examine a variety of LRP1 ligands. This was important because the LRP1 ligands studied here bind to alternative cellular receptors that might also trigger cell signaling. For example, in prostate cancer cells, activated $\alpha_{2} \mathrm{M}$ might bind to GRP78, which becomes externalized and associated with the cell surface (Misra et al., 2011). Similarly, tPA might bind to cell surface annexin A2, eliciting diverse responses in endothelial cells and other cell types (Luo and Hajjar, 2013). The ability of $\alpha_{2} \mathrm{M}^{*}$, EItPA and MMP9 to activate ERK1/2 similarly and the ability of two separate LRP1 signaling antagonists (RAP and lactoferrin) to block these responses confirms the essential role of LRP1.
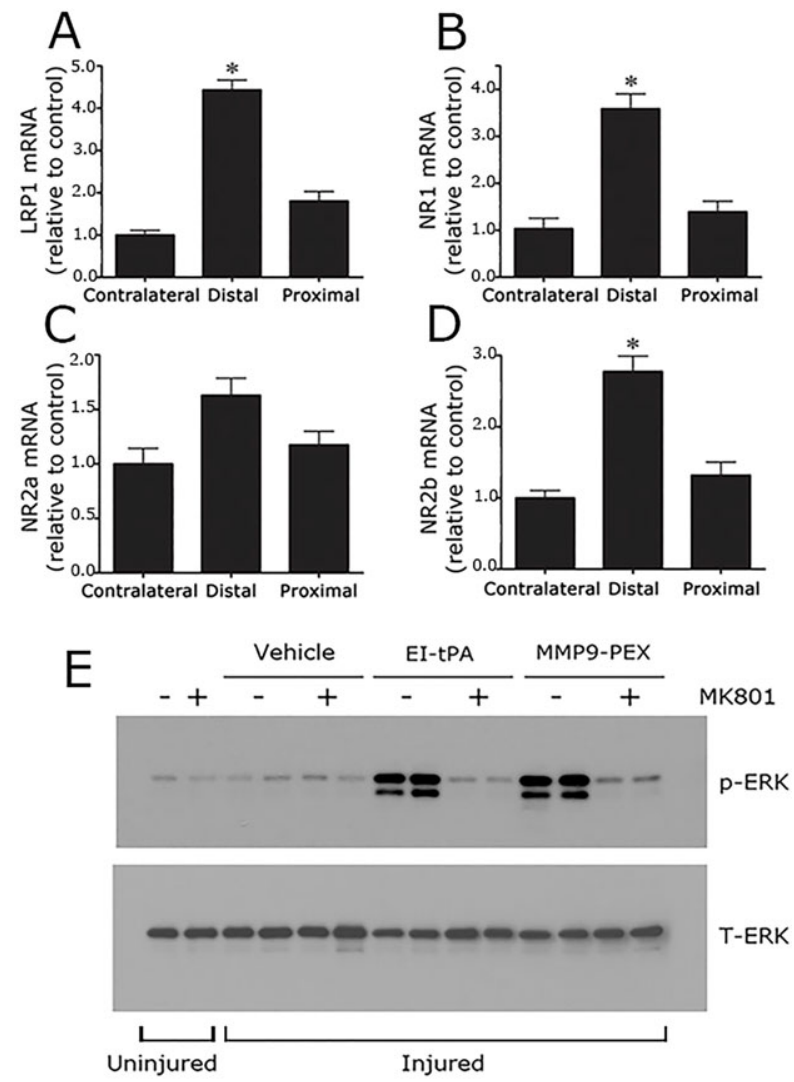

$\mathrm{F}$

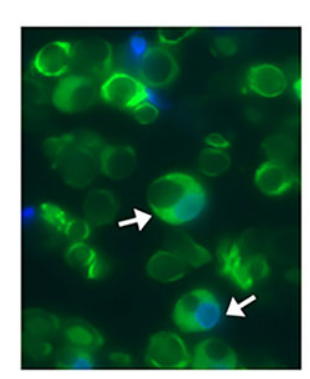

$-\mathrm{MK} 801$

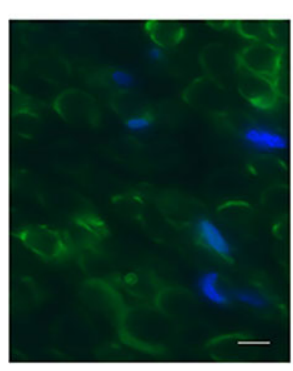

$+\mathrm{MK} 801$

Fig. 8. NMDA-R subunits are expressed at increased levels in the injured sciatic nerve and are essential for Schwann cell LRP1 signaling in vivo. (A) Rat sciatic nerves were subjected to crush injury. Nerve tissue distal to the crush injury site and proximal to the injury site was recovered at the time of killing, $24 \mathrm{~h}$ after surgery. Contralateral nerve tissue was recovered as a control. LRP1 (A), NR1 (B), NR2a (C) and NR2b (D) mRNA levels were determined in each nerve tissue sample by qRT-PCR. mRNA expression results are presented as the fold increase in $\mathrm{mRNA}$, relative to the contralateral nerve (mean \pm s.e.m., $n=4,{ }^{*} P<0.05$ ). (E) Rats were subjected to sciatic nerve crush injury (injured) or sham operation (uninjured). After $24 \mathrm{~h}$, the rats were treated systemically with $0.1 \mathrm{mg} / \mathrm{kg} \mathrm{MK801} \mathrm{(+)} \mathrm{or} \mathrm{with} \mathrm{vehicle} \mathrm{(-).} \mathrm{After} \mathrm{another}$ $30 \mathrm{~min}$, El-tPA, MMP9-PEX ( $2 \mu \mathrm{l}$ of $5 \mu \mathrm{M}$ stock) or vehicle was injected directly into crush-injured nerves. Uninjured nerves were not injected. Nerve tissue distal to the injury site was harvested $15 \mathrm{~min}$ later. Immunoblot analysis was performed to detect phosphorylated ERK1/2 (p-ERK) and total ERK1/2 (T-ERK). The figure shows results from two separate animals for each condition with crush-injured nerves. A single replicate is shown for the sham operation (+ or - MK801). (F) Rats were subjected to sciatic nerve crush injury, treated with MK801 or with vehicle, and injected with EI-tPA (directly into the injured sciatic nerve). Immunofluorescence microscopy was performed to detect p-ERK1/2 distal to the injury site. Images were acquired at $200 \times$ magnification. Scale bar: $10 \mu \mathrm{m}$. Note the presence of p-ERK1/2

immunoreactivity (green) in Schwann cell crescents (see arrows). DAPI (blue) identifies nuclei. The images are representative of those acquired in six separate animals. 
tPA might be unique compared with the other LRP1 ligands studied here because tPA activated ERK1/2 in Schwann cells when LRP1 was blocked, albeit with delayed kinetics. The activity of the NMDA-R as an independent but less-efficient tPA signaling receptor in the absence of LRP1 in Schwann cells is equivalent to the activity observed previously in PC12 and N2a cells (Mantuano et al., 2013). These data support a model in which tPA binds with low affinity to LRP1 or the NMDA-R. Simultaneous coupling to both cell surface receptors apparently provides an optimal response, increasing the sensitivity of the signaling system. In addition to binding to the NMDA-R, tPA might cleave NMDA-R subunits in reactions that affect receptor function (Nicole et al., 2001; Fernández-Monreal et al., 2004;). In our studies, we examined enzymatically inactive tPA (EI-tPA) and confirmed that active tPA (EA-tPA) generates similar signaling responses. The signaling activity demonstrated by EI-tPA and the effects of EI-tPA on Schwann cell migration show that tPA is an active signaling protein in Schwann cells, independently of its proteolytic activity.

Although our results are the first to suggest that tPA might regulate Schwann cell physiology by binding directly to Schwann cell NMDA-R, previous studies have shown that tPA is indeed a robust regulator of the response to PNS injury. tPA is expressed by Schwann cells in culture (Alvarez-Buylla and Valinsky, 1985) and in vivo (Akassoglou et al., 2000), and is up-regulated in the sciatic nerve, together with other fibrinolysis proteins, following nerve injury (Siconolfi and Seeds, 2001). Akassoglou et al. (2000), demonstrated that tPA deficiency in mice exacerbates demyelination and axonal damage following sciatic nerve injury. Although these effects have been attributed to excessive fibrinogen deposition in the injured nerve, our data suggest that interaction of tPA with Schwann cell NMDA-R and LRP1 might have also contributed to these results.

Our new model in which the NMDA-R functions as a cell signaling receptor in Schwann cells alone, and as part of a cell signaling system with LRP1, does not preclude the function of other gene products as part of the NMDA-R-LRP1 signaling system. In neurons, post-synaptic density protein-95 (PSD-95, also known as DLG4) is an important component of this signaling system, physically coupling LRP1 to the NMDA-R (May et al., 2004). This interaction might be potentiated by ligand binding to LRP1 (Mantuano et al., 2013). Trk receptors also are required for cell signaling downstream of LRP1 and the NMDA-R in neurons and neuron-like cells (Shi et al., 2009; Yoon et al., 2013). Because we do not have evidence for the function of Trk receptors in LRP1 signaling in Schwann cells (Shi et al., 2009), the activity of other receptor tyrosine kinases merits consideration.

In conclusion, we have shown that Schwann cells express the NMDA-R and that this receptor is a potentially important regulator of Schwann cell physiology in PNS injury. Schwann cell NMDA-R functions as a co-receptor for diverse LRP1 ligands and as an independent receptor for tPA, activating cell signaling and promoting Schwann cell migration. The NMDA-R also promotes Schwann cell survival under challenging conditions.

\section{MATERIALS AND METHODS \\ Proteins and reagents}

$\alpha_{2} \mathrm{M}$ was purified from human plasma by the method of Imber and Pizzo (1981) and activated for binding to LRP1 by dialysis against $200 \mathrm{mM}$ methylamine $\mathrm{HCl}\left(\alpha_{2} \mathrm{M}^{*}\right)$, as previously described (Gonias et al., 1982). Modification of $\alpha_{2} \mathrm{M}$ by methylamine was confirmed by demonstrating the characteristic increase in $\alpha_{2} \mathrm{M}$ electrophoretic mobility by non-denaturing PAGE (Barrett et al., 1979). EI-tPA and EA-tPA were purchased from
Molecular Innovations (Southfield, MI). The NMDA-R antagonist, MK801, was from Calbiochem. Lactoferrin and fibronectin were purchased from Sigma-Aldrich (St Louis, MO). The LRP1-ligand-binding antagonist RAP was expressed as a GST fusion protein (GST-RAP) in bacteria and purified as previously described (Herz et al., 1991). The hemopexin domain of MMP9, which includes the LRP1-binding site in MMP9 (MMP9-PEX; Mantuano et al., 2008a,b), was expressed as a GST fusion protein in bacteria. MMP9-PEX was partially purified by selective detergent extraction (Webb et al., 1998) and then purified to homogeneity by chromatography on a glutathione-Sepharose column (Mantuano et al., 2008a,b). All GST fusion proteins were subjected to urea treatment, dialysis and chromatography on Detoxi-Gel endotoxin-removing columns (Pierce). For immunoblotting experiments, rabbit polyclonal antibodies that detect $\mathrm{p}$ ERK1/2, total ERK1/2, the NR1 subunit of the NMDA-R and the NR2b subunit of NMDA-R, and horseradish-peroxidase-conjugated secondary antibody were purchased from Cell Signaling Technologies (Beverly, MA). For immunofluorescence microscopy studies, polyclonal antibody against the NR1 subunit was from Abcam (Cambridge, MA) and rabbit monoclonal antibody that detects p-ERK1/2 was from Cell Signaling Technologies (Beverly, MA).

\section{Cell culture}

Sciatic nerves were isolated from 1-day-old Sprague Dawley rats. Schwann cells were isolated and enriched by removing fibroblasts using fibronectinspecific antibody and rabbit complement cytolysis, as described previously (Campana et al., 2006). The final preparations consisted of 98\% Schwann cells, as determined by immunofluorescence microscopy for S100 $\beta$, which is a specific Schwann cell marker. Primary cultures of Schwann cells were maintained in low-glucose Dulbecco's modified Eagle's medium (DMEM; Hyclone) containing 10\% FBS (Hyclone), $100 \mathrm{U} / \mathrm{ml}$ penicillin, $100 \mu \mathrm{g} / \mathrm{ml}$ streptomycin, $21 \mu \mathrm{g} / \mathrm{ml}$ bovine pituitary extract and $4 \mu \mathrm{m}$ forskolin (complete medium) at $37^{\circ} \mathrm{C}$ under humidified $5 \% \mathrm{CO}_{2}$. Schwann cell cultures were passaged no more than six times before conducting experiments. Rat PC12 pheochromocytoma cells were obtained from the ATCC (catalog no. CRL-1721) and cultured in high-glucose DMEM (Invitrogen) containing 10\% FBS, 5\% heat-inactivated horse serum (Omega Scientific Inc.), penicillin (100 units $/ \mathrm{ml})$ and streptomycin $(1 \mathrm{mg} / \mathrm{ml})$.

\section{Gene silencing}

Rat NR1-specific siRNA ON-TARGETplus SMARTpool, which targets the NR1 subunit of the NMDA-R, and pooled non-targeting control (NTC) siRNA were from Dharmacon. Schwann cells $\left(2 \times 10^{6}\right)$ were transfected with NR1-specific siRNA $(50 \mathrm{nM})$ or with NTC siRNA $(50 \mathrm{nM})$ by electroporation using the Cell Line Nucleofector Kit V (Amaxa). The degree of gene silencing was determined at the mRNA level by qRT-PCR and at the protein level by immunoblot analysis. Cell signaling and migration experiments were performed $24-36 \mathrm{~h}$ after introducing the siRNAs.

\section{qRT-PCR}

Total RNA was isolated using the RNeasy Kit (Qiagen, Valencia, CA, USA). cDNA was synthesized with the iScript cDNA Synthesis Kit (BioRad, Hercules, CA, USA). qRT-PCR was performed using a System 7300 instrument (Applied Biosystems, Carlsbad, CA) and a one-step program: $95^{\circ} \mathrm{C}, 10 \mathrm{~min} ; 95^{\circ} \mathrm{C}, 30 \mathrm{~s}, 60^{\circ} \mathrm{C}, 1 \mathrm{~min}$ for 40 cycles (primer sequences are available from the corresponding author upon request). GAPDH mRNA levels were determined in each sample as a normalizing gene. We and others (Macdonald et al., 2001; Campana et al., 2006) have shown that GAPDH is an appropriate and relatively stable housekeeping gene in peripheral nerve injury. mRNA levels were calculated by the relative quantity $\left(\Delta \Delta C_{t}\right)$ method. Experiments were performed in triplicate, with internal duplicate determinations

\section{Immunofluorescence microscopy}

Schwann cells in culture were fixed with fresh $4 \%$ paraformaldehyde in $20 \mathrm{mM}$ sodium phosphate, $150 \mathrm{mM} \mathrm{NaCl}, \mathrm{pH} 7.4$ (PBS) for $15 \mathrm{~min}$ at $22^{\circ} \mathrm{C}$ and then permeabilized in $0.25 \%$ Triton X-100 in PBS (PBS-T). Nonspecific binding sites were blocked with $1 \%$ BSA in PBS-T for 30 min 
at room temperature. Cells then were incubated overnight at $4^{\circ} \mathrm{C}$ with primary antibody against NR1 subunit in PBS with $0.5 \%$ Tween 20 and $1 \%$ BSA. Next, cells were incubated with Alexa-Fluor-488-conjugated secondary antibodies in $1 \% \mathrm{BSA}$ for $1 \mathrm{~h}$ at $22^{\circ} \mathrm{C}$ in the dark. Preparations were mounted on slides using Pro-long Gold with DAPI for nuclear labeling. Images were captured using a Leica DMIRE2 fluorescence microscope.

\section{Immunoblot analysis}

Schwann cells were plated at a density of $2 \times 10^{6}$ cells per well in serumcontaining medium and cultured until $\sim 70 \%$ confluent. The cultures were then transferred into serum-free medium (SFM) for $1 \mathrm{~h}$ before adding $\alpha_{2} \mathrm{M}^{*}$, EI-tPA, MMP9-PEX or vehicle. MK801 $(1 \mu \mathrm{M})$, GST-RAP $(150 \mathrm{nM})$, lactoferrin $(150 \mathrm{nM})$ or GST were added $30 \mathrm{~min}$ before adding stimulants, as indicated. Incubations were conducted for $10 \mathrm{~min}$. The cells were then rinsed twice with ice-cold PBS. Cell extracts were prepared in RIPA buffer (PBS with $1 \%$ Triton X-100, $0.5 \%$ sodium deoxycholate, $0.1 \%$ SDS, protease inhibitor mixture and sodium orthovanadate). The protein concentration in cell extracts was determined by bicinchoninic acid assay. An equivalent amount of cellular protein $(40 \mu \mathrm{g})$ was subjected to $10 \%$ SDS-PAGE and electrotransferred onto nitrocellulose membranes. The membranes were blocked with $5 \%$ nonfat dried milk powder in $20 \mathrm{mM}$ Tris$\mathrm{HCl}, 150 \mathrm{mM} \mathrm{NaCl}, \mathrm{pH} 7.4$ with Tween 20 and incubated with primary antibodies. The membranes were then washed and treated with horseradishperoxidase-conjugated secondary antibodies for $1 \mathrm{~h}$. Immunoblots were developed by enhanced chemiluminescence (Perkin Elmer). Each experiment was performed at least three times.

\section{Cell migration assays}

Schwann cell migration was studied using $6.5-\mathrm{mm}$ Transwell chambers with $8 \mu \mathrm{m}$ pores (Corning Costar, Corning, NY), as previously described (Mantuano et al., 2008a,b). The bottom surface of each membrane was coated with $10 \mu \mathrm{g} / \mathrm{ml}$ fibronectin. We selected fibronectin as the substratum because, after peripheral nerve injury, fibronectin expression is induced to provide a provisional matrix for nerve regeneration (Akassoglou et al., 2000). Schwann cells in Sato medium (Bottenstein and Sato, 1980) supplemented with $1 \mathrm{mg} / \mathrm{ml} \mathrm{BSA}$ were treated with $\alpha_{2} \mathrm{M}^{*}(10 \mathrm{nM})$, EI-tPA $(12 \mathrm{nM})$ or vehicle for $10 \mathrm{~min}$ at $37^{\circ} \mathrm{C}$. In some cases, the cells were pretreated with MK801 $(1 \mu \mathrm{M})$ or GST-RAP $(150 \mathrm{nM})$ prior to adding LRP1 ligands. Reagents were added at the same concentration to the medium in the Transwell chambers. The bottom chamber contained $10 \%$ FBS. Cells $\left(10^{5}\right)$ were transferred to the top chamber of each Transwell chamber and allowed to migrate at $37^{\circ} \mathrm{C}$ in $5 \% \mathrm{CO}_{2}$. After $4 \mathrm{~h}$, the upper surface of each membrane was cleaned with a cotton swab. The membranes then were stained with Diff-Quik (Dade-Behring, Deerfield, IL). The number of cells on the bottom surface of each membrane was counted. Four fields were examined on each filter. Each condition was studied in triplicate.

\section{Cell death studies}

Primary cultures of Schwann cells transfected with NTC siRNA or NR1specific siRNA were plated at $10^{4}$ cells per well in 96-well plates coated with $10 \mu \mathrm{g} / \mathrm{ml}$ fibronectin. Cells were cultured overnight in complete medium. The cells were then retained in complete medium, re-equilibrated in DMEM containing $0.5 \%$ FBS (low-serum medium, LSM), transferred to Sato media (Bottenstein and Sato, 1980), or treated with TNF $\alpha(50 \mathrm{ng} / \mathrm{ml})$ in LSM for $18 \mathrm{~h}$. Cell death was measured using the cell death ELISA (Roche), a colorimetric assay that measures intracytoplasmic oligonucleosomes (Mantuano et al., 2008a,b).

\section{Cell signaling in sciatic nerves in vivo}

Experiments were performed using adult male Sprague-Dawley rats $(200 \mathrm{~g})$ from Harlan Laboratories (San Diego, CA), which were housed in pairs with a 12-h-light-12-h-dark cycle and ad libitum access to food and water. For surgery, rats were anesthetized with $2 \%$ isoflurane (IsoSol; VedCo, St. Joseph, MO). Using a sterile field, the left sciatic nerve was crushed once for $2 \mathrm{~s}$ at the sciatic nerve notch with flat forceps (Myers et al., 2003). The muscle layer then was closed using 6.0 silk sutures, followed by the skin. After $12 \mathrm{~h}$, when Schwann cell LRP1 expression is substantially increased (Campana et al., 2006), rats were re-anesthetized and treated by intraperitoneal injection with either MK801 $(0.1 \mathrm{mg} / \mathrm{kg})$ or vehicle (PBS). 30 min later, $2.0 \mu \mathrm{l}$ of EI-tPA, MMP9-PEX (5 $\mu \mathrm{M}$ stock) or vehicle (PBS) ( $n=4$ /group) was injected directly into the sciatic nerve fascicle at the crush injury site. Nerve tissue distal to the crush injury site $(0.3 \mathrm{~cm})$ was collected 15 min after injecting the LRP1 ligands, together with contralateral nerve. In control experiments, un-injured rat sciatic nerves were injected with EI-tPA, MMP-PEX ( $5 \mu \mathrm{M}$ stock) or PBS ( $n=4 /$ group). Nerve tissue was harvested 15 min later. Extracts of sciatic nerve were isolated in RIPA buffer for immunoblot analysis. For immunofluorescence microscopy microscopy studies (see below), the rats were perfused transcardially with 4\% paraformaldehyde in $0.1 \mathrm{M}$ phosphate buffer, $\mathrm{pH} 7.4$ prior to collecting sciatic nerve tissue. The rats were killed by intraperitoneal injection of an overdose of anesthetic cocktail containing ketamine $(100 \mathrm{mg} / \mathrm{kg}$ body weight; Phoenix Scientific, St Joseph, MO) and xylazine $(10 \mathrm{mg} / \mathrm{kg}$ body weight; Boerhinger Pharmaceutical, St. Joseph, MO) followed by cervical dislocation. All procedures were performed according to protocols approved by the University of California, San Diego Committee on Animal Research, and conform to the NIH Guidelines for Animal Use.

\section{Immunofluorescence microscopy analysis of crush-injured sciatic nerve}

Distal sciatic nerve $(0.3 \mathrm{~cm})$ was recovered. The resected tissue was immersed in fixative for $2 \mathrm{~h}$ at $4^{\circ} \mathrm{C}$ and then transferred to $20 \%$ sucrose in PBS overnight. Serial $10 \mu \mathrm{m}$ sections were prepared using a cryostat and mounted on Superfrost Plus Micro Slides (VWR, West Chester, PA). Polyclonal primary antibody, specific for phosphorylated ERK1/2 (1:500), was applied overnight at $4{ }^{\circ} \mathrm{C}$. After washing with Tris-buffered saline with Tween 20 three times, the sections were incubated with Alexa-Fluor-488conjugated goat anti-rabbit-IgG antibody $(5 \mu \mathrm{g} / \mathrm{ml})$ for $1 \mathrm{~h}$. In control studies, the primary antibody was omitted; no specific immunoreactivity was observed. Nuclei were stained with mounting medium containing DAPI (Invitrogen, Carlsbad, CA). All slides were covered with slips and visualized using a Leica DMIRE2 fluorescence microscope. Images were obtained using a $63 \times$ oil-immersion objective and a Hamamatsu digital camera with SimplePCI software.

\section{Statistical analysis}

For all of the presented studies, replicates refer to separate experiments, typically performed with internal duplicates or triplicates. Results of cell migration, cell death, and in vivo cell signaling experiments were subjected to analysis of variance (ANOVA). A Tukey's post hoc analysis was performed to assess differences between treatment groups.

\section{Competing interests}

The authors declare no competing or financial interests.

\section{Author contributions}

E.M., W.M.C. and S.L.G. designed research; E.M., M.S.L. and M.S. performed research; E.M., M.S.L., M.S., W.M.C. and S.L.G. analyzed data; E.M., W.M.C. and S.L.G. wrote the paper

\section{Funding}

This work was supported by the National Institutes of Health [grant numbers HL-060551 and NS-057456]; and from the Italian Ministry of Education, Universities, and Research, FIRB 2013 [grant number RBFR13BPK9]. Deposited in PMC for release after 12 months.

\section{References}

Akassoglou, K., Kombrinck, K. W., Degen, J. L. and Strickland, S. (2000) Tissue plasminogen activator-mediated fibrinolysis protects against axonal degeneration and demyelination after sciatic nerve injury. J. Cell Biol. 149, 1157-1166.

Alvarez-Buylla, A. and Valinsky, J. E. (1985). Production of plasminogen activato in cultures of superior cervical ganglia and isolated Schwann cells. Proc. Natl. Acad. Sci. USA 82, 3519-3523.

Arthur-Farraj, P. J., Latouche, M., Wilton, D. K., Quintes, S., Chabrol, E., Banerjee, A., Woodhoo, A., Jenkins, B., Rahman, M., Turmaine, M. et al. (2012). C-Jun reprograms Schwann cells of injured nerves to generate a repair cell essential for regeneration. Neuron 75, 633-647. 
Asbury, A. K. and Johnson, P. C. (1978). Pathology of peripheral nerve. Major Probl. Pathol. 9, 1-311.

Bacskai, B. J., Xia, M. Q., Strickland, D. K., Rebeck, G. W. and Hyman, B. T. (2000). The endocytic receptor protein LRP also mediates neuronal calcium signaling via N-methyl-D-aspartate receptors. Proc. Natl. Acad. Sci. USA 97, $11551-11556$.

Barrett, A. J., Brown, M. A. and Sayers, C. A. (1979). The electrophoretically 'slow' and 'fast' forms of the alpha 2-macroglobulin molecule. Biochem. J. 181, 401-418.

Bliss, T. V. P. and Collingridge, G. L. (1993). A synaptic model of memory: longterm potentiation in the hippocampus. Nature 361, 31-39.

Bottenstein, J. E. and Sato, G. H. (1980). Fibronectin and polylysine requirement for proliferation of neuroblastoma cells in defined medium. Exp. Cell Res. 129 361-366.

Brown, D. G. and Krupp, J. J. (2006). N-methyl-D-aspartate receptor (NMDA) antagonists as potential pain therapeutics. Curr. Top. Med. Chem. 6, 749-770.

Bu, G., Williams, S., Strickland, D. K. and Schwartz, A. L. (1992). Low density lipoprotein receptor-related protein/alpha 2-macroglobulin receptor is an hepatic receptor for tissue-type plasminogen activator. Proc. Natl. Acad. Sci. USA 89 7427-7431

Campana, W. M. (2007). Schwann cells: activated peripheral glia and their role in neuropathic pain. Brain Behav. Immunol. 21, 522-527.

Campana, W. M., Li, X., Dragojlovic, N., Janes, J., Gaultier, A. and Gonias, S. L. (2006). The low-density lipoprotein receptor-related protein is a pro-survival receptor in Schwann cells: possible implications in peripheral nerve injury. J. Neurosci. 26, 11197-11207.

Castillo, C., Norcini, M., Martin Hernandez, L. A., Correa, G., Blanck, T. J., Recio-Pinto, E. (2013). Satellite glia cells in dorsal root ganglia express functiona NMDA receptors. Neuroscience. 240, 135-146

Edwards, M. A., Loxley, R. A., Williams, A. J., Connor, M., Phillips, J. K. (2007) Lack of functional expression of NMDA receptors in PC12 cells. Neurotoxicology. 2, 876-885

Evans, P. D., Reale, V., Merzon, R. M. and Villegas, J. (1991). N-methyl-Daspartate (NMDA) and non-NMDA type glutamate receptors are present on squid giant axon SCs. J. Exp. Biol. 157, 593-600.

Everts, I., CVillmann, C. and Hollmann, M. (1997). N-Glycosylation is not a prerequisite for glutamate receptor function but is essential for lectin modulation. Mol. Pharmacol. 52, 861-873

Ferrari, L. F., Lotufo, C. M., Araldi, D., Rodrigues, M. A., Macedo, L. P., Ferreira, S. H., Parada, C. A. (2014). Inflammatory sensitization of nociceptors depends on activation of NMDA receptors in DRG satellite cells. Proc. Natl. Acad. Sci. U S A 111, 18363-18368.

Fernández-Monreal, M., López-Atalaya, J. P., Benchenane, K., Cacquevel, M., Dulin, F., Le Caer, J.-P., Rossier, J., Jarrige, A.-C., MacKenzie, E. T., Colloc'h, N. et al. (2004). Arginine 260 of the amino-terminal domain of NR1 subunit is critical for tissue-type plasminogen activator-mediated enhancement of N-methyl-D-aspartate receptor signaling. J. Biol. Chem. 279, 50850-50856.

Fink, T., Davey, D. F. and Ansselin, A. D. (1999). Glutaminergic and adrenergic receptors expressed on adult guinea pig Schwann cells in vitro. Can. J. Physiol. Pharmacol. 77, 204-210.

Fuentealba, R. A., Liu, Q., Kanekiyo, T., Zhang, J. and Bu, G. (2009). Low density lipoprotein receptor-related protein 1 promotes anti-apoptotic signaling in neurons by activating Akt survival pathway. J. Biol. Chem. 284, 34045-34053.

Furukawa, H., Singh, S. K., Mancusso, R. and Gouaux, E. (2005). Subunit arrangement and function in NMDA receptors. Nature 438, 185-192.

Gonias, S. L. and Campana, W. M. (2014). LDL receptor-related protein-1: a regulator of inflammation in atherosclerosis, cancer, and injury to the nervous system. Am. J. Pathol. 184, 18-27.

Gonias, S. L., Reynolds, J. A. and Pizzo, S. V. (1982). Physical properties of human alpha2-macroglobulin following reaction with methylamine and trypsin Biochim. Biophys. Acta 705, 306-314.

Hayashi, H., Campenot, R. B., Vance, D. E. and Vance, J. E. (2007) Apolipoprotein E-containing lipoproteins protect neurons from apoptosis via a signaling pathway involving low-density lipoprotein receptor-related protein-1. J. Neurosci. 27, 1933-1941.

Herz, J., Goldstein, J. L., Strickland, D. K., Ho, Y. K. and Brown, M. S. (1991). 39$\mathrm{kDa}$ protein modulates binding of ligands to low density lipoprotein receptorrelated protein/ $\alpha 2-$ macroglobulin receptor. J. Biol. Chem. 266, 21232-21238.

Hoe, H.-S., Tran, T. S., Matsuoka, Y., Howell, B. W. and Rebeck, G. W. (2006) DAB1 and Reelin effects on amyloid precursor protein and ApoE receptor 2 trafficking and processing. J. Biol. Chem. 281, 35176-35185.

Hussaini, I. M., Srikumar, K., Quesenberry, P. J. and Gonias, S. L. (1990) Colony-stimulating factor-1 modulates alpha 2-macroglobulin receptor expression in murine bone marrow macrophages. J. Biol. Chem. 265, 19441-19446.

Imber, M. J., Pizzo, S. V. (1981). Clearance and binding of two electrophoretic "fast" forms of human alpha 2-macroglobulin. J. Biol. Chem. 256, 8134-8139.

Jansen, M. and Dannhardt, G. (2003). Antagonists and agonists at the glycine site of the NMDA receptor for therapeutic interventions. Eur. J. Med. Chem. 38 661-670

Jessen, K. R., Mirsky, R. (2005). The origin and development of glial cells in peripheral nerves. Nat. Rev. Neurosci. 6, 671-682.
Ji, R. R., Kohno, T., Moore, K. A., Woolf, C. J. (2003). Central sensitization and LTP do pain and memory share similar mechanisms? Trends. Neurosci. 26, 696-705 Jopling, C., Boue, S. and Izpisua Belmonte, J. C. (2011). Dedifferentiation, transdifferentiation and reprogramming: three routes to regeneration. Nat. Rev. Mol. Cell Biol. 12, 79-89.

Kemp, J. A. and McKernan, R. M. (2002). NMDA receptor pathways as drug targets. Nat. Neurosci. 5 Suppl, 1039-1042.

Lalo, U., Pankratov, Y., Kirchhoff, F., North, R. A. and Verkhratsky, A. (2006) NMDA receptors mediate neuron-to-glia signaling in mouse cortical astrocytes. J. Neurosci. 26, 2673-2683.

Lichnerova, K., Kaniakova, M., Park, S. P., Skrenkova, K., Wang, Y.-X., Petralia, K. S., Suh, Y. H. and Horak, M. (2015). Two N-glycosylation sites in the GluN1 subunit are essential for releasing NMDA receptors from the endoplasmic reticulum. J. Biol. Chem. 290, 18379-18390.

Li, C., Xiao, L., Liu, X., Yang, W., Shen, W., Hu, C., Yang, G., He, C. (2013). A functional role of NMDA receptor in regulating the differentiation of oligodendrocyte precursor cells and remyelination. Glia. 61, 732-749.

Luo, M. and Hajjar, K. A. (2013). Annexin A2 system in human biology: cell surface and beyond. Semin. Thromb. Hemost. 39, 338-346.

Lynch, M. A. (2004). Long-term potentiation and memory. Physiol. Rev. 84, 87-136.

Macrez, R., Bezin, L., Le Mauff, B., Ali, C., Vivien, D. (2010). Functiona occurrence of the interaction of tissue plasminogen activator with the NR1 Subunit of N-methyl-D-aspartate receptors during stroke. Stroke. 41, 2950-2955.

Mantuano, E., Mukandala, G., Li, X., Campana, W. M. and Gonias, S. L. (2008a) Molecular dissection of the human $\alpha-2$ macroglobulin subunit reveals domains with antagonistic activities in cell signaling. J. Biol. Chem. 283, 19904-19911.

Mantuano, E., Inoue, G. Li, X., Takahashi, K. Gaultier, A., Gonias, S. L. and Campana, W. M. (2008b). The hemopexin domain of matrix metalloproteinase- 9 activates cell signaling and promotes migration of Schwann cells by binding to Low-density Lipoprotein Receptor-related Protein. J. Neurosci. 28, 11571-11582.

Mantuano, E., Jo, M., Gonias, S. L. and Campana, W. M. (2010). Low density lipoprotein receptor-related protein (LRP1) regulates Rac1 and RhoA reciprocally to control Schwann cell adhesion and migration. J. Biol. Chem. 285 14259-14266.

Mantuano, E., Henry, K., Yamauchi, T., Hiramatsu, N., Yamauchi, K., Orita, S. Takahashi, K., Lin, J. H., Gonias, S. L. and Campana, W. M. (2011). The unfolded protein response is a major mechanism by which LRP1 regulates Schwann cell survival after injury. J. Neurosci. 31, 13376-13385.

Mantuano, E., Lam, M. S. and Gonias, S. L. (2013). LRP1 assembles unique coreceptor systems to initiate cell signaling in response to tissue-type plasminogen activator and myelin-associated glycoprotein. J. Biol. Chem. 288, 34009-34018.

Martin, A. M., Kuhlmann, C., Trossbach, S., Jaeger, S., Waldron, E., Roebroek A., Luhmann, H. J., Laatsch, A., Weggen, S., Lessmann, V. et al. (2008). The functional role of the second NP XY motif of the LRP1 beta-chain in tissue-type plasminogen activator-mediated activation of $\mathrm{N}$-methyl-D-aspartate receptors. J. Biol. Chem. 283, 12004-12013.

May, P., Rohlmann, A., Bock, H. H., Zurhove, K., Marth, J. D., Schomburg, E. D. Noebels, J. L., Beffert, U., Sweatt, J. D., Weeber, E. J. et al. (2004). Neuronal LRP1 functionally associates with postsynaptic proteins and is required for normal motor function in mice. Mol. Cell. Biol. 24, 8872-8883.

Meier, C., Parmantier, E., Brennan, A., Mirsky, R. and Jessen, K. R. (1999) Developing SCs acquire the ability to survive without axons by establishing an autocrine circuit involving insulin-like growth factor, neurotrophin-3, and plateletderived growth factor-BB. J. Neurosci. 19, 3847-3859.

Micu, I., Jiang, Q., Coderre, E., Ridsdale, A., Zhang, L., Woulfe, J., Yin, X., Trapp B. D., McRory, J. E., Rehak, R. et al. (2006). NMDA receptors mediate calcium accumulation in myelin during chemical ischaemia. Nature 439, 988-992.

Misra, U. K., Pizzo, S. V. (2015). Activated $\alpha 2$-macroglobulin binding to human prostate cancer cells triggers insulin-like responses. J. Biol. Chem. 290, 9571-9587. Missale, C., Fiorentini, C., Busi, C., Collo, G. and Spano, P. F. (2006). The NMDA D1 receptor complex as a new target in drug development. Curr. Top. Med. Chem. 6, 801-808.

Myers, R. R., Sekiguchi, Y., Kikuchi, S., Scott, B., Medicherla, S., Protter, A. Campana, W. M. (2003). Inhibition of p38 MAP kinase activity enhances axonal regeneration. Exp. Neurol. 184, 606-614.

Nacher, J. and McEwen, B. S. (2006). The role of N-methyl-D-asparate receptors in neurogenesis. Hippocampus 16, 267-270.

Ney, K. A., Gidwitz, S. and Pizzo, S. V. (1985). Binding and endocytosis of alpha 2-macroglobulin-plasmin complexes. Biochemistry 24, 4586-4592.

Ng, D., Pitcher, G. M., Szilard, R. K., Sertié, A., Kanisek, M., Clapcote, S. J. Lipina, T., Kalia, L. V., Joo, D., McKerlie, C., Cortez, M., Roder, J. C., Salter, M. W., Mclnnes, R. R. (2009). Neto1 is a novel CUB-domain NMDA receptorinteracting protein required for synaptic plasticity and learning. PLoS Biol. 7, e41. Nicole, O., Docagne, F., Ali, C., Margaill, I., Carmeliet, P., MacKenzie, E. T., Vivien, D. and Buisson, A. (2001). The proteolytic activity of tissue-plasminogen activator enhances NMDA receptor-mediated signaling. Nat. Med. 7, 59-64.

Orita, S., Henry, K., Mantuano, E., Yamauchi, K., De Corato, A., Ishikawa, T. Feltri, M. L., Wrabetz, L., Gaultier, A., Pollack, M. et al. (2013). Schwann cell LRP1 regulates Remak bundle ultrastructure and axonal interactions to prevent neuropathic pain. J. Neurosci. 33, 5590-5602. 
Polavarapu, R., Gongora, M. C., Yi, H., Ranganthan, S., Lawrence, D. A., Strickland, D. and Yepes, M. (2007). Tissue-type plasminogen activatormediated shedding of astrocytic low-density lipoprotein receptor-related protein increases the permeability of the neurovascular unit. Blood 109, 3270-3278.

Qiu, Z., Strickland, D. K., Hyman, B. T. and Rebeck, G. W. (2002). Alpha2macroglobulin exposure reduces calcium responses to $\mathrm{N}$-methyl-d-aspartate via low density lipoprotein receptor-related protein in cultured hippocampal neurons. J. Biol. Chem. 277, 14458-14466.

Rajan, I. and Cline, H. (1998). Glutamate receptor activity is required for normal development of tectal cell dendrites in vivo. J. Neurosci. 18, 7836-7846.

Salter, M. G. and Fern, R. (2005). NMDA receptors are expressed in developing oligodendrocyte processes and mediate injury. Nature 438, 1167-1171.

Samson, A. L., Nevin, S. T., Croucher, D., Niego, B., Daniel, P. B., Weiss, T. W., Moreno, E., Monard, D., Lawrence, D. A. and Medcalf, R. L. (2008). Tissue-type plasminogen activator requires a co-receptor to enhance NMDA receptor function. J. Neurochem. 107, 1091-1101.

Sheng, Z., Prorok, M., Brown, B. E. and Castellino, F. J. (2008). N-methyl-Daspartate receptor inhibition by an apolipoprotein E-derived peptide relies on lowdensity lipoprotein receptor-associated protein. Neuropharmacology 55, 204-214.

Shi, Y., Mantuano, E., Inoue, G., Campana, W. M. and Gonias, S. L. (2009). Ligand binding to LRP1 transactivates Trk receptors by a Src family kinasedependent pathway. Sci. Signal. 2, ra18.
Siconolfi, L. B. and Seeds, N. W. (2001). Induction of the plasminogen activator system accompanies peripheral nerve regeneration after sciatic nerve crush J. Neurosci. 21, 4336-4347.

Stiles, T. L., Dickendesher, T. L., Gaultier, A., Fernandez-Castaneda, A., Mantuano, E., Giger, R. J. and Gonias, S. L. (2013). LDL receptor-related protein-1 is a sialic-acid-independent receptor for myelin-associated glycoprotein that functions in neurite outgrowth inhibition by MAG and CNS myelin. J. Cell Sci. 126, 209-220.

Strickland, D. K., Gonias, S. L. and Argraves, W. S. (2002). Diverse roles for the LDL receptor family. Tends Endocrinol. Metab. 13, 66-74.

Van Horn, M. R., Sild, M., Ruthazer, E. S. (2013). D-serine as a gliotransmitter and its roles in brain development and disease. Front. Cell. Neurosci. 7, 39

Wang, Y. T., Salter, M. W. (1994). Regulation of NMDA receptors by tyrosine kinases and phosphatases. Nature. 369, 233-235.

Webb, D. J., Wen, J., Karns, L. R., Kurilla, M. G. and Gonias, S. L. (1998). Localization of the binding site for transforming growth factor-beta in human alpha2-macroglobulin to a 20-kDa peptide that also contains the bait region. J. Biol. Chem. 273, 13339-13346

Wu, S.-Z., Jiang, S., Sims, T. J. and Barger, S. W. (2005). Schwann cells exhibit excitotoxicity consistent with release of NMDA receptor agonists. J. Neurosci. Res. 79, 638-643.

Yoon, C., Van Niekerk, E. A., Henry, K., Ishikawa, T., Orita, S., Tuszynski, M. H. and Campana, W. M. (2013). Low-density lipoprotein receptor-related protein 1 (LRP1)-dependent cell signaling promotes axonal regeneration. J. Biol. Chem. 288, 26557-26568 